\title{
QUEENSLAND: A RETURN TO THE MOONLIGHT STATE?
}

\section{KATE GALLOWAY and ALLAN ARDILL}

\author{
(2014) 39(1) Alternative Law Journal 3.
}

Lately there has been a lot made in the media about a war on bikies and the implementation of other new laws, ostensibly designed to meet the expectations of Queenslanders that the government is getting tough on crime. ${ }^{1}$ Lawyers across the board have condemned the Queensland laws as ill-conceived, rash, hurried, irresponsible, self-serving and dangerous, consistently mentioning attacks on the rule of law, our system of government, and the separation of powers. ${ }^{2}$ In response to the critique, Premier Campbell Newman has alleged that lawyers should 'step out of their ivory towers'. ${ }^{3}$ While the legal principles at stake may seem overly technical or abstract, history reveals their importance in protecting rights and freedoms of citizens. As a former Chief Justice of the High Court commented:

Judicial independence does not exist to serve the judiciary; nor to serve the interests of the other two branches of government. It exists to serve and protect not the governors but the governed... The reason why judicial independence is of such public importance is that a free society exists only so long as it is governed by the rule of law - the rule which binds the governors and the governed, administered impartially and treating equally all those who seek its remedies or against whom its remedies are sought. 4

Observing the interaction between the three arms of government in Queensland, this article explains the importance of these legal concepts, their practical significance, why the 'war on crime' in Queensland has implications for all Australians, and why all citizens should be wary of this latest Trojan Horse - the war on criminals.

\section{Evolution of the rule of law and its practical importance}

Parliamentary democracy resulted from a long and sometimes violent struggle to curb the injustices of hierarchical feudal society and its arbitrary and brutal use of concentrated power to afford a greater say for ordinary people. The 1215 Magna Carta was an early example of the limits put on the arbitrary will of the King — though it shored up the power of the barons. Following this, principles emerged of what could be loosely described as the rule of law ${ }^{5}$ and constitutional law. Notably the rule of law featured in the English revolutions of the 17th Century, the French Revolution and the American Constitution. ${ }^{6}$ Former Chief Justice Murray Gleeson pointed out that even in the Australian context there have been 'gradual, and peaceful, but substantial' ${ }^{7}$ transitions towards the rule of law. Gleeson describes the essence of the rule of law as that 'all authority is subject to, and constrained by law.

Likewise, constitutional law developed for both pragmatic reasons and as a result of the struggles between an emerging middle class seeking freedom from the tyranny and arbitrary rule of a feudal system. A key plank of constitutionalism was the separation of power between the arms of state: the Crown and its officials, the parliament, and the judiciary. Notably in the 1607 Case of Prohibitions del Roy the Court declared:

The King in his own person cannot adjudge any case, either criminal or betwixt party and party; but it ought to be determined and adjudged in some Court of Justice, according to the law and custom of England. ${ }^{9}$

This is a clear indication that courts were starting to require a separation between the power of monarch and the judiciary - signalling what emerged as a protracted dispute between these arms of government.

In 1610 in Dr Bonham's Case the court affirmed the principle that the judiciary retains an inherent power to review the laws made by parliament: 'when an Act of Parliament is against common right and reason, or repugnant, or impossible to be performed, the common law will controul [sic] it, and adjudge such Act to be void'. ${ }^{10}$ Similarly, in the 1611 Case of Proclamations the court declared that the King could not simply make new crimes by royal proclamation. ${ }^{11}$ These battles between the arms of state continued over time to develop into recognised and settled conventions understood today as the doctrine of the separation of powers.

The importance of this doctrine lies in the way in which the rights, conventions, laws and principles constituting the separation of powers place a brake on the concentration of power in a single absolute, potentially despotic, arm of government. ${ }^{12}$

Together, the rule of law and separation of powers - and some would suggest that the latter is integral to the former ${ }^{13}$ - form the backbone of governance and legal procedure, and protect civil liberties (human rights) of the citizen. Yet in contemporary Western democracies, these principles are being threatened - for example, in the name of the 'war on terrorism',14 or in the Queensland context, in the name of a 'war' on outlaw motorcycle clubs. In Queensland, the threat is manifesting on a number of levels. First, in the text of a suite of laws that seek to wind back human rights considered central to just process of the law. Secondly, the process undertaken in passing the laws challenges conceptions of good governance within the rule of law. Thirdly, is the challenge of the authority of the courts by the Executive government in terms of the separation of powers.

\section{The rule of law in Queensland}

These issues are of particular concern in Queensland in light of its political history. Unlike the other Australian states, Queensland has had no upper house of parliament since the abolition of the Legislative Council on 23 March 1922. This was followed by long periods of dominance by a single party - notably the continuous rule of the National Party in Queensland from 1957 to 1989 . With its reputation as a police state, persistent questions dogged the Queensland government and police service concerning institutional relationships with organised crime. Eventually, following an investigation by journalist Chris Masters on the ABC's Four Corners program 'The Moonlight State', then Acting Premier Bill Gunn established the terms of reference for what was to become known as the Fitzgerald Inquiry.

The Fitzgerald Inquiry ran from 1987 to 1989 and found corruption rife within executive government and the police service. Tony Fitzgerald, who headed the Inquiry, reported that this was facilitated by an executive that was dominant over parliament and the judiciary and through poor law-making processes in a unicameral parliament. Without making a specific finding that parliamentary dominance of the National Party was supported by a gerrymander, the Inquiry acknowledged the lack of public confidence in a se- 
cret and unaccountable electoral boundary process, recommending electoral reform. ${ }^{15}$ Finally, he observed that corruption was supported by a complacent media. ${ }^{16}$ The Crime and Misconduct Commission ('CMC') was established in response to Inquiry recommendations, and charged with oversight of the criminal justice system.

Despite the long history of the rule of law and separation of powers in general, and even with the respected work of Fitzgerald to restore integrity to the Queensland system in particular, recent legislative developments seem to abrogate these tenets of good governance.

\section{Getting 'tough on bikies'}

For some years now in Australia, bikies have been identified by law enforcement agencies as engaging in organised crime. Some legislation in South Australia and New South Wales attempting to outlaw bikie gangs has been struck down by the High Court. ${ }^{17}$ The latest of such laws to come into force are in Queensland in response to a so-called 'war on bikies' arising from two recent wellpublicised and graphic incidences of violence involving some people with connections to outlaw motorcycle gangs.

\section{As Morgan, Dagistanli and Martin point out in the NSW context, such 'violent incidents' provide:}

the optimal conditions under which the views of those seeking to push the state in a more coercive and punitive direction can flourish. They are the points at which new phrases are invented to capture the horrors described in the media reports, the character and appearance of 'folk devils' are enumerated in fine detail and new categories of deviant behaviour emerge that appear to require amendments to criminal law. ${ }^{18}$

In other words, there has been very little evidence provided of the nature of the alleged criminal activities of these gangs but (perhaps) exaggerated concern over public disorder. There is however increasing evidence of authorities losing their war on drugs and evidence that drug prohibition fuels criminal activity. ${ }^{19}$

While describing the past, Fitzgerald could just have easily been describing the present government responses in Queensland when he observed that criminal justice is a complex matter:

Problems, when they emerge, tend to be presented as isolated dilemmas with simple solutions, and Governments are often tempted to solve them by passing laws forbidding certain behaviour. This is often done without any real research and without any regard to the ability of the law enforcement system, including the Police, the courts and the prisons, to cope with the burden of extra enforcement.

Passage of such a law usually, however, gives the Minister responsible a sense of accomplishment, leaves the bureaucracy in control, and gives the public an impression that the Government is alert and active. The media rarely examines the issues in any depth, often endorsing the view that problems have simple solutions which can be applied by quick legislation. ${ }^{20}$

Despite these observations and evidence in the discipline of criminology and in the law (cited above) the government has introduced a suite of laws that return to status-based offences that challenge contemporary understanding of criminality.

\section{Criminalising association}

The new laws rest on the foundation of criminalisation of association, whereby a citizen will be guilty of an offence not for doing an act, nor for planning an act, but by the company they keep. An organisation can be declared criminal by regulation; by the courts (upon application); or by virtue of participation with two others for a 'serious criminal purpose'. ${ }^{21}$ So far, 26 gangs have been declared criminal organisations under the Criminal Code (Criminal Organisations) Regulation 2013 (QId) ('the Criminal Code') and the Crime and Misconduct Regulations 2005 (QId).

Under amendments to the Criminal Code, ${ }^{22}$ participants in a criminal organisation who are 'knowingly present' in a public place with two or more other participants in a criminal organisation, are guilty of an offence charged with a minimum sentence of six months to be served 'wholly in a correctional facility'.

Additionally, a list of addresses, purportedly bikie clubhouses (though they are not called that) are 'prescribed places' under the Criminal Code. It is an offence under s $60 \mathrm{~B}(4)$ of the Criminal Code for a member of a criminal organisation to enter any prescribed place. It is also an offence to wear or carry clothing and jewellery marked with the insignia or names of a criminal organisation into licensed premises. $^{23}$

The implications for participants in a criminal organisation go further however. Under the Vicious Lawless Associations Disestablishment Act 2013 (QId) ('VLAD Act') the commission of one of the scheduled offences by a participant in a criminal organisation brings with it a mandatory additional sentence of 10 years. There is an additional mandatory 15 years for those who are officebearers. Members of criminal organisations who are arrested are to be denied bail ${ }^{24}$ unless the defendant shows cause why custody is not justified. If bail is granted, they are required to surrender their passport. These provisions apply regardless of whether the offence is an indictable, simple or regulatory offence.$^{25}$ The provisions were amended soon after their introduction because a grammatical error created a loophole that excluded bikies who had renounced their colours. The amendments now ensure the application of the Act to those who are, and were, bikies. ${ }^{26}$

The powers of the CMC have been extended, with particular application to members of criminal organisations. All who appear before the CMC are compelled to answer questions on pain of contempt. However it is no longer a 'reasonable excuse' for participants in criminal organisations to refuse to answer questions on the basis of a fear of physical harm or property damage to themselves or those close to them. ${ }^{27}$ The court must punish contempt by imprisonment to be served wholly in a corrective services facility. ${ }^{28}$ Being charged with contempt attracts penalties for a first offence at the discretion of the court, but the penalty for a second offence is two and a half years and a third offence, five years. ${ }^{29}$ Furthermore, the provisions of the Bail Act apply to contempt as for other offences - so participants of criminal organisations will be denied bail as a matter of course.

According to statements by the government, further laws have been introduced to 'prevent racketeering'. ${ }^{30}$ New regulations of tattoo parlours will require business owners and employed tattooists to apply for a licence. ${ }^{31}$ They are required to provide fingerprints and palm prints, and may be refused a licence if they are not a 'fit and proper person' or it is 'contrary to the public interest'. Refusal may be made on the grounds of 'criminal intelligence'. There are calls also to ban participants in criminal organisations from other industries, such as security. ${ }^{32}$

Freedom of association is not protected by a bill of rights in Queensland. Australia however is a signatory to the International Covenant on Civil and Political Rights ('ICCPR') and the International Covenant on Economic, Social and Cultural Rights ('ICESCR'), both of which contain the right to freedom of association. In spite of the lack of domestic statutory protection, the right is one that is 
taken for granted.

Under the new legislation the right of association is only removed for those who participate in a 'criminal organisation' and who associate with other participants. However there is no requirement for any criminal intent involved in the association (for example, planning a crime). Laws already exist to arrest, charge and detain those who are suspected of having committed an offence. These new laws however make association itself an offence and put in train a series of other laws and policies such as refusal of bail, mandatory additional sentences and harsher conditions of imprisonment. In doing so, these laws overturn the presumption of innocence, the principle of proportionality of sentencing and principles of punishment.

While there may not be public sympathy for a group demonised and deemed criminal by the media, the laws are widely drafted and would apply beyond 'criminal bikie gangs'. This is particularly so when considered in conjunction with other planks of the government's law and order program.

\section{Expanding police powers to search and detain}

In advancing its law and order platform, the G20 Safety and Security Act 2013 was introduced into Parliament in anticipation of the G20 meetings to be held in Brisbane and Cairns in 2014. The Act provides (among other things) for:

- the declaration of security areas for the purpose of the $\mathrm{G} 20{ }^{33}$

- organisation (including registration) of lawful assembly; ${ }^{34}$

- police searches, including strip searches, in security areas; ${ }^{35}$

- the declaration of prohibited persons, who are not to enter security areas; ${ }^{36}$

- the exclusion of certain people from security areas; ${ }^{37}$

- an offence to carry 'prohibited items' within security areas, and for them to be seized; ${ }^{38}$

- arrest without warrant, ${ }^{39}$ and detention if the person is charged with an offence under another Act; ${ }^{40}$

- presumption against bail for those arrested for assault of a police officer, discharging a missile at a police officer, or generally otherwise disrupting the $\mathrm{G} 20$ meeting. ${ }^{41}$

While some of these powers would be familiar in the context of a short-term international gathering of high level dignitaries, they nevertheless erode civil liberties. What is particularly interesting is the potential for the interaction between these laws and the socalled 'anti-bikie' legislation.

If for example an otherwise peaceful (and lawful) assembly turns violent, there is the possibility for people to be charged with affray, one of the offences listed as a trigger for operation of the VLAD Act. Carrying out such an act with three others deemed to be participants in a serious crime then renders the accused a participant in a criminal organisation. This would attract the additional mandatory sentences. This answers the Opposition's cynical criticism of the $\mathrm{G} 20$ laws that the sentences were not sufficient, ${ }^{42}$ but indicates also the potential sweep of the new laws beyond 'criminal bikie gangs'.

\section{Suspect political process}

While the text and implications of these laws have been widely criticised, so too have the process of their introduction. This can be illustrated with reference to a number of issues canvassed by the Fitzgerald Inquiry.

Importantly, the present government's overwhelming parliamentary majority - indeed, one that is disproportionate to the 49.66 per cent of the overall vote ${ }^{43}$ — has afforded enormous power to both the Parliament and the Executive.

Aroney points out that the value of an upper house lies in 'democratic representation, public deliberation, legislative outputs and scrutiny of executive government'. ${ }^{44}$ The return of an upper house is unlikely. In response to a petition to reinstate the upper house, the Premier was dismissive citing a recent survey of 70000 Queenslanders who 'are not raising the need for more politicians.' 45

The Fitzgerald Inquiry criticised the then Executive's domination of the Parliament — with the collusion of an uncritical public service keen to please, and an apathetic media that simply reported what it was told. ${ }^{46}$

A Government can use its control of Parliament and public administration to manipulate, exploit and misinform the community, or to hide matters from it. Structures and systems designed for the purpose of keeping the public informed must therefore be allowed to operate as intended. ${ }^{47}$

Further, Fitzgerald pointed out the necessity for a separation of the offices of Attorney-General and Minister for Justice, to ensure dispassionate critique of proposals for law reform. ${ }^{48}$ The present Attorney-General, 'unapologetic' for the government's 'tough on crime' stance, is also Minister for Justice. In that regard, Fitzgerald observed:

In consequence, there has been no real critical assessment within the Government of draft legislation. Further, there has been no mechanism by which fresh points of view could be expressed. ${ }^{49}$

Apart from the G20 Act, there seems to have been little if any engagement in a system of parliamentary oversight of these laws via a committee system, another of the Fitzgerald recommendations. The Opposition claimed to have had only hours to consider the bills mentioned above, and the Queensland Law Society ${ }^{50}$ issued a statement expressing disappointment at the lack of consultation. Fitzgerald's comments from 1989 could well apply today: ' ... the bureaucrats had the last word, and wrote the submissions and statements which went to Cabinet, the party room and Parliament. ${ }^{51}$

To the extent that some have indicated the CMC is a de facto 'house of review', its independence has been compromised by an unsolicited opinion piece by its acting head, Dr Ken Levy who gave unqualified and enthusiastic support for the laws. ${ }^{52}$ The Parliamentary Crime and Misconduct Committee ('PCMC') subsequently found that Dr Levy had not fully disclosed the extent of discussions he had with a government staffer before his opinion piece. In a political context that sees almost daily unfolding of new challenges to principles of governance, the Queensland government's response to this was to use its huge majority in Parliament to sack the PCMC. ${ }^{53}$

On the same day it published Dr Levy's piece, the Courier Mail likewise strongly supported the Government's stance. In an editorial on 27 October, it proclaimed that 'extraordinary times called for extraordinary measures. ${ }^{, 54}$ On 31 October, it called on jurists to run for parliament if they were not happy with the new laws. ${ }^{55}$ While playing to the moral panic described by Morgan, Dagistanli and 
Martin ${ }^{56}$ these editorials fail to appreciate the fundamental issues at stake with the sense of entitlement displayed by the Executive, particularly the Premier and Attorney-General, in relation to the laws. Citing 'evidence' that 70 per cent of Queenslanders supported the laws is hardly evidence either of the need for the laws, or that the laws are the most effective way to deal with the apparent problem.

As foreshadowed by the Courier Mail's editorial however, the issue of Executive dominance has expanded in a test of the power of the government as against the Courts.

\section{Judicial independence}

While the separation between Executive and the Parliament is incomplete in Australian jurisdictions, the focus of the doctrine of separation of powers lies as between Executive and Parliament, and the Courts. More specifically addressed in the Commonwealth Constitution, the extent of the separation of institutions of governance in the states is less clear.

In addition to there being no constitutional foundation for the separation of powers in Queensland, the doctrine of separation of powers sits alongside the doctrine of parliamentary supremacy - whereby Parliament itself is sovereign. This means that the Parliament may make laws overturning a court ruling, for example, and that the Courts are required to enforce laws passed by Parliament. This is not to say however that there are no bounds to the power of Parliament, or that the courts are completely beholden to the whim of Parliament. Each institution is required to operate in its own sphere, as a consequence of two principles.

The first of these is the separation of powers which as a principle is adopted by convention. Second, and relatedly, under the operation of the Commonwealth Constitution there are limits to parliamentary supremacy because the Constitution recognises the State Courts as part of the constitutional court hierarchy. ${ }^{57}$ While the Commonwealth Constitution does not import the separation of powers to state constitutions, the institutional integrity of the Supreme Court must be maintained, although this is a 'notion not readily susceptible in terms which will dictate future outcomes. ${ }^{, 58}$

This has been illustrated in two recent challenges ${ }^{59}$ to Queensland's sex offender laws. Under the Criminal Law Amendment (Public Interest Declarations) Amendment Act 2013, the Attorney-General has ultimate power to override parole and court decisions and to detain a convicted sex offender indefinitely. The Queensland Court of Appeal however found that 'these amendments are within that exceptional category of legislation which is invalid on the ground that it is repugnant to that institutional integrity of the Supreme Court'. ${ }^{60}$ They attributed to the executive the role of the judiciary on a case-by-case basis, without any right of review vested in the citizen.

Though the Queensland Attorney-General has now rejected appealing to the High Court, the general approach of the Court of Appeal can be considered in terms of Gleeson's description of the rule of law - that all authority is subject to, and constrained by law $^{61}$ - even, in the case of parliament, where authority is 'paramount'. It is these limits that are presently being tested in Queensland.

The Premier started with a call to the judiciary to enforce the laws enacted by Parliament. As outlined above, these laws include mandatory refusal of bail, mandatory additional sentences and mandatory findings of contempt. Mandatory sentencing has been upheld as a valid exercise of parliamentary power - even though it appears to erode the separation of powers through its removal of the checks and balances afforded by judicial consideration. Such laws are likely only to be valid, however, where they do not involve the exercise of a judicial power by the executive. ${ }^{62}$

In an early test of the laws, Magistrate Bernadette Callaghan was not satisfied that an accused was in fact a member of a criminal organisation and granted him bail. Police therefore faced an unexpected hurdle in enforcing the new laws - despite the assumption of criminality by association. The Premier's widely reported disappointment at the decision demanded that the Queensland judiciary should start realising what the community wants and act accordingly. 'To protect the community — that's all the Government is after [and] that is all the Queensland community is after. ${ }^{63}$

Consequently Fryberg $\mathrm{J}$ stayed the appeal of the DPP, giving the prosecution the opportunity to clarify the comments or have the Premier withdraw them. His concern was that the statement may result in a perception that the Court was not applying the law, but simply complying with the government's wishes. In Parliament, the Premier affirmed his statement. On reconvening, the prosecution refused to assist the Court with its request and the matter was permanently stayed. ${ }^{64}$

Justice Fryberg's decision was overturned by the Court of Appeal ${ }^{65}$ which found that it would take more than the Premier's comments to undermine the independence of the judiciary. Still, the Premier's statements are concerning not in that he was calling on the Courts to apply the law. Rather, he was calling on the Courts to act on the basis of 'community standards'. As Fryberg J pointed out, this would be contrary to the oath of office of the judge, and allowing the Premier's comments to stand would compromise the independence of the court. As for the importance of judicial independence, Brennan $\mathrm{J}$ has said:

In these and in other areas of jurisdiction involving the citizen and government, the impartial application of the rule of law demands independence of the judicial branch of government from the political branches of government. And ... that independence continues to be essential to the due administration of the criminal law. If that independence were, or were thought by the litigants or the public to be, put at risk, the rule of law would be imperilled and the peace and order of society would be problematic. ${ }^{66}$

The Premier's public statements therefore go to the very heart of the separation of powers and independence of the judiciary. With little critical oversight by Parliament, with a docile CMC and complacent press, the judiciary is all that stands between the citizen and the government. The rule of law, ensuring that all authority is itself constrained by law, demands this. Without this buffer, the risk is that the Executive, for political reasons, implements laws that execute themselves.

Perhaps the Premier's statements go to the heart of a profound misunderstanding of the judicial system within the community. It may also explain the Premier's comment that 'the legal fraternity [are] living literally (sic) in an ivory tower.' He called on the profession to "come out of your ivory towers" and realise the only reason the government introduced a raft of tough new laws was because the "system was failing"., 67

What the Premier failed to acknowledge however, as discussed above, is that simplistic 'solutions' implemented reactively in re- 
sponse to a problem without adequate investigation and consultation, inevitably impose greater and unforeseen burdens on the justice system. One of those is the possibility for the erosion of the rule of law. And as has been discussed above, this is the cornerstone protection for each citizen, including those in society who are unpopular or who fail to fit prevailing norms.

\section{Conclusion}

Other states are looking with interest at the developments in Queensland, particularly the validity of bikie laws which have been struck down elsewhere. The power relationship between the government and the people may well be tested beyond Queensland's jurisdiction. Additionally, while the judiciary may have been under attack in Queensland, the political stance underlying government action also knows no state boundary. It is important to governance Australia-wide that public confidence in the judiciary, and the separation of powers, is upheld. To do otherwise risks an imbalance in the power of institutions of governance. While it is tempting to support tough laws to deal with criminal bikies, property-destroying anarchists and serious-sex offenders, these laws go much further. They directly and indirectly impact on each citizen through concentrating power in the hands of too few.

This concentration of power in Queensland followed the 2012 election and afforded enormous power to both the Parliament and the Executive. The Executive is enforcing an overtly populist legislative agenda that is bypassing the few checks available within the unicameral system which could otherwise reveal the extent to which they wind back civil liberties. Finally, the government itself through legislation and public comment is eroding public confidence in the judiciary and simultaneously seeking to wind back its independence, replacing judicial review with Executive order. Each of these factors is an essential element of effective and accountable governance, a each has been removed or threatened.

The absence of these essential hallmarks of good governance give rise to a concern that Queensland might return to an era when the extreme concentration of power in the executive branch of government created opportunity for misuse of that power. The simultaneous winding back of civil liberties recalls the term of the Bjelke-Petersen government during which people were jailed as political prisoners, persecuted for their beliefs, driven into exile and lost their livelihoods for questioning the government or the police. ${ }^{68}$ We suggest that failure to attend scrupulously to the highest standards of systems of governance and balancing institutional powers leaves open the real possibility of a failure of individuals within that system to exercise that power appropriately. This in itself represents a failure of the system as a whole.

Fitzgerald has said that the system of governance is more important than individual wrongdoing. However the political culture he described in his report in 1989 still seems to exist. Is it possible that we can expect, as part of that culture, more of the same?

KATE GALLOWAY teaches law at the James Cook University, and ALLAN ARDILL teaches law at Griffith University.

Addendum: Since this article was written, the Queensland Court of Appeal overturned the permanent stay declared in $R v B r o w n$ [2013] QSC 299. The point, however had already been made by Fryberg J.

\section{(C) 2014 Kate Galloway and Allan Ardill}

\section{REFERENCES}

1. Note, eg, Courier Mail editorials: 'Newman Government's Anti-Bikie Crusade is a War Worth Fighting', 28 October 2013 $<$ http://www.couriermail.com.au/news/opinion/editorial-newman-governments-antibikie-crusade-is-a-war-worth-fighting/storyfnihsr9v-1226747886150>; 'Jurists should Remember the Reasons for Bikies Crackdown', 1 November 2013 <http://www.couriermail.com.au/news/opinion/editorial-jurists-should-remember-the-reasons-for-bikies-crackdown/story-fnihsr9v1226750861064>.

2. Queensland Law Society ('QLS'), 'Legislative Rush Impacts the Rights of All Queenslanders' (Media Release, 17 October 2013); QLS, 'Government Endangers Democracy with Separation of Powers Breach' (Media Release, 24 October 2013); Stephen Keim SC, 'Queensland LNP Trashes Democracy and Rights' Independent Australia, 31 October 2013

<http://www.independentaustralia.net/politics/politics-display/queensland-Inp-trashes-democracy-and-rights,5848>; Richard Chesterman, 'Attorney-General Jarrod Bleijie's Amendment to the Dangerous Prisoners (Sexual Offenders) Act will breed contempt', Courier Mail Online, 22 October 2013 <http://www.couriermail.com.au/news/opinion/opinion-attorneygeneral-jarrod-bleijiesamendment-to-the-dangerous-prisoners-sexual-offenders-act-will-breed-contempt/story-fnihsr9v-1226744059579>.

3. Amy Remeikis, 'Campbell Newman tells Lawyers to Leave "Ivory Towers"' Brisbane Times Online, 24 October 2013 <http://www.brisbanetimes.com.au/queensland/campbell-newman-tells-lawyers-to-leave-ivory-towers-20131024-2w318.html>. Dowsett $\mathrm{J}$ impliedly responded to this, referring to 'ivory towers' in his Address to Graduates: QUT Faculty of Law Graduation Ceremony, QUT, 9 December 2013.

4. Gerard Brennan, 'Judicial Independence' (Speech delivered to the Australian Judicial Conference, ANU, Canberra, 2 November 1996) <http://www.hcourt.gov.au/assets/publications/speeches/former-justices/brennanj/brennanj_ajc.htm>.

5. E R Hardy Ivamy (ed), Mozley \& Whiteley's Law Dictionary (Butterworths, 10th ed, 1988) 424: 'The doctrine that all men are equal before the law, and that acts of officials in carrying out government orders are cognisable in the ordinary courts of law.'

6. See further, the English Bill of Rights 1689 (An Act Declaring the Rights and Liberties of the Subject and Settling the Succession of the Crown) and the Act of Settlement 1700; Declaration of the Rights of Man - 1789 (National Assembly of France, August 26, 1789); and US Constitution Bill of Rights, and the Fourteenth Amendment XIV - Citizen rights not to be abridged (Passed by Congress 13 June 1866 and ratified 9 July 1868).

7. Murray Gleeson, 'Courts and the Rule of Law' (Speech delivered at The Rule of Law Series, University of Melbourne, 7 November 2001).

8. Ibid.

9. Case of Prohibitions del Ray 77 ER 1342, 1342.

10. Dr Bonham's Case 77 ER 646, 652.

11. Case of Proclamations 77 ER 1352, 1354.

12. Explained in the Queensland context: How Government Works <http://www.qld.gov.au/about/how-government-works/system-ofgovernment/>. 
13. See, eg, Gleeson, above $\mathrm{n} 7$.

14. Owen Fiss, 'The War against Terrorism and the Rule of Law' (2006) 26(2) Oxford Journal of Legal Studies 235.

15. GE (Tony) Fitzgerald, Report of a Commission of Inquiry Pursuant to Orders in Council: Commission of Inquiry into Possible Illegal Activities and Associated Police Misconduct (1989) 127, 143-5.

16. Ibid.

17. Wainohu v New South Wales [2011] HCA 24; South Australia v Totani [2010] HCA 39.

18. George Morgan, Selda Dagistanli and Greg Martin, 'Counter-terrorism and Moral Panic over "Bikie Gang Wars" in New South Wales' (2010) 43 ANZ Journal of Criminology 580, 581 (citations omitted).

19. See generally, ABC Radio National, 'Illegal Drugs', Rear Vision, 25 March 2012

<http://www.abc.net.au/radionational/programs/rearvision/illegal-drugs/3894358>.

20. Fitzgerald, above n 15, 140.

21. Criminal Code (QId), s 1 definition 'criminal association'.

22. Criminal Code (QId), s 60A.

23. Liquor Act 1992 (QId), ss173EA-ED.

24. Bail Act 1980 (QId), s 16(3A).

25. Ibid s 16(3C).

26. Bail Act 1980 (QId), s16 (3A).

27. Crime and Misconduct Act 2001 (Qld), s 190(4).

28. Ibid s 198A (8A).

29. Ibid s 198A (8B).

30. Acting Premier/Attorney-General \& Minister for Justice, 'Tough new laws to combat criminal gangs' (Joint Media Statement, 30 September 2013) <http://statements.qld.gov.au/Statement/2013/9/30/tough-new-laws-to-combat-criminal-gangs>.

31. Tattoo Parlour Act 2013 (QId).

32. 'Round two of anti-bikie laws on way in Qld', news.com.au (online), 18 November 2013

<http://www.news.com.au/national/breaking-news/round-two-of-anti-bikie-laws-on-way-in-qld/story-e6frfku9-1226762426100>.

33. G20 Safety and Security Bill 2013, s 7.

34. Ibid ss 18-19.

35. Ibid ss 23-25.

36. Ibid s 50 .

37. Ibid s 55

38. Ibid s 59 .

39. Ibid s 78 .

40. Ibid s 79 .

41. Ibid s 82.

42. Jason Tin, 'Queensland Parliament Pass New Laws to Extend Police Powers during G20', The Australian (Sydney), 30 October 2013 <http://www.theaustralian.com.au/news/queensland-parliament-pass-new-laws-to-extend-police-powers-during-g20/storye6frg6n6-1226749323513>.

43. Electoral Commission Queensland, 'Total Formal First Preference Vote by Party' $<$ http://www.ecq.qld.gov.au/elections/state/state2012/results/summary.html\#13>.

44. Nicholas Aroney, 'Four Reasons for an Upper House' (2008) 29 Adelaide Law Review 205.

45. Fidelis Rego, 'No Upper House Needed for Queensland, Premier Campbell Newman Says', ABC News Online, 25 November 2013 <http://www.abc.net.au/news/2013-11-25/no-upper-house-needed-for-qld-parliament-newman-says/5114170>.

46. Fitzgerald, above $\mathrm{n} 15$.

47. Ibid 126.

48. Ibid 138.

49. Ibid 139.

50. QLS Media Release, 17 October 2013, above n 2.

51. Ibid.

52. Ken Levy, 'Strong Anti Gang Laws Vital to Shield the Innocent in Bikie Battle says CMC Boss', Courier Mail (Brisbane), 27 October 2013 <http://www.couriermail.com.au/news/opinion/opinion-strong-antigang-laws-vital-to-shield-the-innocent-in-bikie-battlesays-cmc-boss/story-fnihsr9v-1226750041912>.

53. Stephanie Small, Brad Ryan and staff, 'Call for Judicial Inquiry after Qld Government Sacks PCMC Members' ABC Online, 22 November 2013 <http://www.abc.net.au/news/2013-11-22/call-for-judicial-inquiry-after-qld-government-sacks-pcmc/5109756>.

54. 'Newman Government's Anti-Bikie Crusade is a War Worth Fighting', above $\mathrm{n} 1$.

55. 'Jurists Should Remember the Reasons for Bikies Crackdown', above n 1.

56. See above $\mathrm{n} 4$.

57. Suri Ratnapala and Jonathan Crowe, 'Broadening the Reach of Chapter III' (2012) 36 (1) MULR 175; Luke Beck, 'What is a "Supreme Court of a State"?' (2012) 34 Sydney Law Review 295.

58. Assistant Commissioner Condon v Pompano Pty Ltd (2013) 87 ALJR 458, [123-6].

59. Attorney-General (Queensland) v Lawrence [2013] QCA 364; Attorney-General (Queensland) v Fardon [2013] QCA 365.

60. Attorney-General (Queensland) v Lawrence [2013] QCA 364, [42]. 
61. Gleeson, above $\mathrm{n} 4$.

62. See, eg, Magaming $v$ The Queen [2013] HCA 40.

63. $R$ v Brown [2013] QSC 299 [3].

64. $R$ v Brown [2013] QSC 299.

65. The Queen v Brown [2013] QCA 337.

66. Brennan, above $\mathrm{n} 4$.

67. Remeikis, above n 3.

68. Damien Murphy, 'The man who won the battle of Fraser Island quits Queensland', The Age (Melbourne), 26 August 1986, 17; Brian Walters, 'Suing Into Submission: Using Litigation to Quell Dissent' (Public lecture, Castan Centre for Human Rights Law), 9 August 2005 <http://www.law.monash.edu.au/castancentre/events/2005/walters-paper.pdf>; See generally 1985 SEQEB industrial dispute and the notorious legislation, Electricity (Continuity of Supply) Act 1985 (Qld); Matt Foley, Queensland Council for Civil Liberties (Speech for QCCL Award of Life Membership, Mcllwraith Croquet Club, Auchenflower, 27 October 2013)

<http://www.qccl.org.au/documents/Speech_MFoley_270ct13_ThreeDoctorsAGM.pdf>. 